\section{Wojciech Pikor}

Uniwersytet Mikołaja Kopernika w Toruniu wojciech.pikor@umk.pl

ORCID: 0000-0003-2656-152X

DOI: http://dx.doi.org/10.12775/BPTH.2019.022
Biblica

et

Patristica

Thoruniensia

12 (2019) 4: 409-430

ISSN (print) 1689-5150

ISSN (online) 2450-7059

\title{
The Theological Message of the Fourth Servant Song (Isa 52:13-53:12) in Light of Its Structure
}

\section{Orędzie teologiczne czwartej pieśni o Słudze Pańskim (Iz 52,13-53,12) w świetle jej struktury}

\begin{abstract}
The article aims to analyse the structure of Isa 52:13-53:12 deploying elements of the analysis of the biblical and Semitic rhetoric developed by Roland Meynet. The article begins with an overview of earlier scholarly suggestions concerning the structure of the Fourth Servant Song, including Meynet's. The major part of the article constitutes a rhetorical analysis of the song, first as a whole and then within its individual rhetorical units. In the final part of the article, major theological motifs of the song are presented, which are part of a new vision of suffering and death in the context of the Old Testament.
\end{abstract}

Streszczenie. Autor podejmuje się zbadania struktury Iz 52,13-53,12 na podstawie metodologii semickiej i biblijnej retoryki wypracowanej przez Rolanda Meynet. Po zaprezentowaniu dotychczasowych propozycji strukturyzacji czwartej pieśni o Słudze Pańskim, również tej pochodzącej od Meynet, i ich ocenie, następuje analiza retoryczna pieśni w jej całości i poszczególnych jednostkach retorycznych. Na bazie analizy relacji retorycznej pomiędzy poszczególnymi częściami tworzącymi pieśń zostaje ukazane jej przesłanie teologiczne, w którego centrum jest soteriologiczna wizja cierpienia i śmierci, stanowiąca novum wewnątrz Starego Testamentu.

Keywords: Deutero-Isaiah; Fourth Servant Song; rhetorical analysis; soteriology; suffering.

Słowa kluczowe: Deutero-Izajasz; czwarta pieśń o Słudze Pańskim; analiza retoryczna; soteriologia; cierpienie. 
The interpretation of the Fourth Song about the servant of Yahweh has been a subject of an ongoing exegetical debate. The difficulty lies not only in the identification of the servant, but also - as Lech Stachowiak, the author of a Polish commentary on the Book of Isaiah, notes - in "philological [...] and exegetico-literary problems. The speaking persona in the song seems inconsistent, the literary genre is difficult to determine, and the literary structure of the song is unclear." ${ }^{1}$ As for the last of these factors, the present paper wishes to examine the structure of Isa 52:13-53:12 with the use of the elements of Hebrew Biblical rhetoric developed by Roland Meynet. According to Meynet, "biblical texts will seem well constructed if we analyse them on the basis of the rules of biblical rhetoric, and the analysis of their structure will allow us to understand them better as long as it emphasizes their own logic." ${ }^{2}$ The uncovering of the rhetorical structure of the pericope - through the discovery of mutual relations between its parts - makes it possible to see the theological message of the text, which regains this way its dynamic value.

The starting point for my analysis of the structure of the Fourth Servant Song will be a systematic overview of previous studies of the text's structure. The major part of the article will constitute a rhetorical analysis of Isa 52:13$-53: 12$, consisting of the delimitation of major textual units and the examination of their rhetorical structure. The article will end with an attempt to pinpoint the song's major theological themes, which offer a new vision of suffering and death in the context of the Old Testament.

\section{Debate on the Structure of Isa 52:13-53:12}

Bernhard Duhm was the first scholar to pay attention in his 1892 commentary on Isaiah to the texts about the servant of Yahweh, considering them to be an earlier sequence, independent from its current context. ${ }^{3}$ Despite the passing of time, the debates over the songs' autonomy in the so-called Deutero-Isaiah, over their literary genre, their relations with other parts of the book and over their redactional process do not seem to end. As far as the Fourth Servant Song is concerned, scholars tend to agree on its delimitation within the unit of 52:13-53:12.

1 L. Stachowiak, Księga Izajasza II-III (40-60), 216.

2 R. Meynet, Wprowadzenie do hebrajskiej retoryki biblijnej, 180.

3 B. Duhm, Das Buch Jesaja. 
Roger N. Whybray, Harry M. Orlinski and Norman H. Snaith ${ }^{4}$ voice a different opinion, though, excluding the text of 52:13-15 from the whole as a song of gratitude for an earlier prediction of Israel's return from exile in chapter 52. However, these verses should be treated as an integral part of the poem in Isa 53, as borne out by several words forming inclusion: "my servant" (in 52:13 and 53:11); "see" (ראה in 52:15 and 53:11); and "many" (רָרִים in 52:14.15 and 53:11.12[x2]). What is more, there are some median terms (the so-called mots-crochets) that link the text of 52:13-15 with the following poem: "appearance" (מֶרֶמר) and "form"

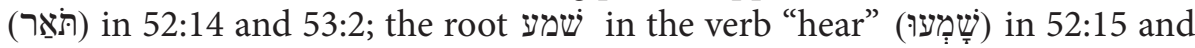
in the noun "report" (שְׁמוּעָה) in 53:1; verbs of the semantic field of understanding: "understand" (בין in Hithpolel) in 52:15 and "believe" (גלהן in Hi) in 53:1, as well as "see" (ראה) in 52:15 and "reveal" (גלה in Ni) in 53:1. ' Alongside the rhetorical aspect, one needs to mention the weakness of the arguments these scholars give concerning the Hebrew Bible's division into chapters following Isa 52:15. As John N. Oswalt shows, the formal division of the Fourth Song was conducted by medieval Jews, who believed that Isa 53 does not correspond to the vision of Messiah sketched in Isa 52:13-15. ${ }^{6}$

From a rhetorical point of view, the analysis of the structure of the Fourth Servant Song should encompass Isa 52:13-53:12. In their analyses of the unit's structure, exegetes deploy various criteria that may be divided into: (1) thematic ones; (2) those identifying the speaker (the voices speaking in the song); (3) poetic ones (stanzas); and rhetorical ones with the focus on (4) recurring words or (5) concentric structures. Acknowledging the autonomy of these approaches, it needs to be assessed whether their results, frequently mutually contradictory, aptly show the structure of the song.

The thematic approach to the song allows for a linear rendering of the servant's suffering and plight. The song is framed by the inclusion formed by the prologue in 52:13-15 - anticipating the servant's elevation following his rejection - and the epilogue in 53:12, predicting the servant's future glory. ${ }^{7}$ It is more difficult to unequivocally determine the subject matter of subsequent units describing the servant's travails. Józef Paściak proposes a conceptual approach that is not limited only to the account of the servant's suffering but also tries to

4 R.N. Whybray, Isaiah 40-66, 169-170; H.M. Orlinski, The so-called 'Servant of the Lord' and 'Suffering Servant' in Second Isaiah, 1977, 17-23; N.H. Snaith, Isaiah 40-66, 134-146.

5 The synonymy of the first two verbs is confirmed by their presence in Isa 43:10, while of the last two - in Isa 40:5 and 47:3.

6 J.N. Oswalt, The Book of Isaiah, 376.

7 J. Paściak, Izajasz wieszczem Chrystusa, 124. 
explain it. Józef Homerski, in turn, draws attention to the text's value as a progressive chronicle of the servant's passover in Isa 53: vv. 1-3 - poverty, suffering and rejection; vv. 4-7 - suffering; v. 8 - death; v. 9 - slander after death; vv. 10-11a - reward and elevation. The thematic structuring of the book seems to stem from pragmatic reasons: the text needs to be somehow ordered before its exegesis can be attempted. As a result, the song's structure evinces a preunderstanding of the text that overlooks formal signs present in it.

The second of the criteria deployed to determine the text's structure namely, the identity of the speaking persona - is more lucid, methodologically speaking. Undoubtedly, it is God who speaks in 52:13-15 and 53:(11-)12. It is more difficult to identify other speakers due to the anonymity of those who speak in the first person plural as well as to the somewhat unclear relationship between the community and the prophet. Some believe that in 53:1-11 the prophet speaks on behalf of the Jews. ${ }^{8}$ Others maintain, however, that it is only the people who speak in this part of the song. ${ }^{9}$ An intermediary position is also possible: it is argued by some that in vv. 1-7 it is the people (Jews) or pagan rulers who speak, while later it is the prophet himself. ${ }^{10}$ The focus placed on the speaker emphasizes a dramatic value of the poem, whereby it seems to be a kind of debate over the meaning of the servant's life. However, the identification of the characters in the poem enables only its partial understanding. The text is then treated solely as a basis for the presentation of individual participants of the poem, while the event conveyed by the text, its illocutionary and perlocutionary values are neglected.

Taking into account the dramatic character of the poem, there have been attempts to determine the identity of the speaker on the basis of the subject matter of the fragment. Klaus Baltzer's opinion is particularly note-worthy: for him, the song is a liturgical drama in six parts, staged during the Passover. Resembling a court case, the drama was supposed to rehabilitate the servant, who

8 Cf. P. Grelot, I canti del servo del Signore, 46-50; J. Blenkinsopp, Isaiah 40-55, 349; B.S. Childs, Isaiah, 411.

9 C. Westermann, Isaiah 40-66, 255-258; B. Marconcini, Księga Izajasza, 362-366; T. Brzegowy, Prorocy Izraela, 186-190.

10 Those who support this point of view are not unanimous when it comes to the exact moment when the speaker changes from the community to the individual. According to Pierre-Emile Bonnard, this happens after v. 6 (Le Second Isaïe, son disciple et leur éditeurs, 269); in Joseph Coppens's view, it occurs after v. 7 (Le Messianisme et sa relève prophétique, 61); while Henri Cazelles argues that it takes place after v. 7a (Les Poèmes du Serviteur, 32-35). The last of them identifies the collective speaker with pagan kings. 
was identified with Moses. ${ }^{11}$ This reading strongly emphasizes the dynamic value of the poem. What is problematic about Baltzer's stance, however, is his view of the life of Moses as the servant of Yahweh, which is then superimposed onto the text of the Fourth Song. ${ }^{12}$

Alongside the interpretation of the song as a drama, there are frequent attempts at seeking its structure in the text's poetic layer. The division into stanzas suggests a certain regularity of the text, but in the majority of cases the criteria of this division are arbitrary. The alleged regular meter of the song or its four- or three-stanza structure are more of a postulate referring to the changing content of the poem. ${ }^{13}$ It is only Jan L. Koole who gives arguments for the division into stanzas that he espouses, yet this is limited only to $53: 2-9 .{ }^{14}$ On the one hand, he mentions the text's concentric structure, corroborated by a double inclusion: first by $52: 13-15$ and $53: 11-12$ as the prologue and the epilogue, and then by 53:1 and 53:10 as the introduction and the conclusion explaining God's plan of salvation realized through the servant's life. The remaining part of the text would then be divided into four stanzas of four lines each: vv. 2-3.4-5.6-7.8-9. The basis of such a division would be the repetition of individual words in the stanzas, which leads to a parallel structure in stanzas one and three and a concentric structure in stanzas two and four. Such a line of argumentation is close to rhetorical analysis, yet it concentrates only on selected repetitions in order to delimit smaller units. It overlooks those repetitions that would entail the interpretation of those parts that correspond to one another.

The phenomenon of repetitions within the Fourth Song has been approached in exegesis several times in the last decades. Paul R. Raabe and Michael L. Barré have composed relatively complete lists of recurring words and expressions, seeking parallel structures in the text. ${ }^{15}$ Their analyses, however, lack a comprehensive overlook on the poem. Raabe maintains that repetitions

11 K. Baltzer, Deutero-Jesaja, 493-543 (the author discusses the arguments for the literary genre of the song in the context of the whole Isa $40-55$ on pages $39-47$ ). The text would encompass the following scenes: 52:13: the servant's speech and elevation; 52:14-15: heavenly judgment beginning with the judge's speech; $53: 1$ : the prosecutors' questions; $53: 2-10$ : the servant's biography - the witnesses' arguments; 53:11: the judge's verdict - word of salvation for the servant; 53:12: the servant's future and new tasks.

12 Cf. C. Conroy, The 'Four Servant Poems' in Second Isaiah in the Light of Recent Redaction-Historical Studies.

13 As an example one may mention the structure suggested by John N. Oswalt, The Book of Isaiah, 376, and Adrian Schenker, Knecht und Lamm Gottes (Jesaja 53), 67-69.

14 J.L. Koole, Isaiah, 262-263.

15 M.L. Barré, Textual and Rhetorical-Critical Observations on the Last Servant Song (Isaiah 52,13-53,12); P.R. Raabe, The Effect of Repetition in the Suffering Servant Song. 
are used in the poem to strengthen the contrast between the servant's degradation and elevation and between his real situation and its assessment by the people. His "bipolar" interpretation of the poem does not lead to any suggestion of the structure of the text. ${ }^{16}$ Barré, in turn, proposes some structure for the poem, but is not methodologically constant. He presupposes that repetitions function as inclusion demarcating smaller units. ${ }^{17}$ Accepting this assumption, he still overlooks the repetition of the word "sheep" in vv. 6a.7b and of words formed from the root חפץ in v. 10 ("want" and "will"), which could suggest that vv. 6-7 and v. 10 are autonomous literary units. To verify this, various criteria of content and form need to be deployed, which both Barré and Raabe fail to do.

These drawbacks in the rhetorical analysis of Isa 52:12-53:12 have gradually been overcome in the studies drawing attention to the concentric structures present in the song. Anthony R. Ceresko takes into account the phenomenon of "distant parallelism", on the basis of which he identifies v. 53:5b as the heart of the poem. ${ }^{18}$ Two layers are situated concentrically around this centre: the inner one in 53:1-5a and 53:6-9, and the outer one in 52:13-15 and 53:10-12. Not all rhetorical observations made by Ceresko seem right or are sufficiently interpreted. Surprisingly, he seeks parallelism between the plant metaphor in 53:2 and the animal metaphor in 53:7. ${ }^{19}$ The fact that he sees repetitions that do not occur in parallel sections is also debatable, e.g. 53:4 with 53:11b-12a. ${ }^{20}$ It is not problematic in itself that he identifies those parallels, but rather that he does not interpret them, just as he fails to interpret repetitions within the parts that he divides the song into (e.g. 53:11 and 53:12).

It was only Roland Meynet's study that offered a comprehensive rhetorical analysis of the Fourth Servant Song. ${ }^{21}$ Meynet sees v. 53:5b as the centre of the poem, with other rhetorical segments in 53:1 and 53:10, around which subse-

16 As a matter of fact, Raabe follows Chistopher R. North and proposes a linear structure of the song (five stanzas: 52:13-15; 53,1-3.4-6.7-9.10-12) even before he starts to analyse the repetitions (The Effect of Repetition, 76-77)

17 Acknowledging the presence of the prologue and epilogue in the poem, Barre divides the remaining fragment of the text into two parts, which contain numerous subparts: A - vv. 1-2.3.4-5.6; B - 7.8.9-10b.11a-c (Textual and Rhetorical, 2-3).

18 A.R. Ceresko, The Rhetorical Strategy of the Fourth Servant Song (Isaiah 52,13-53,12). Poetry and the Exodus-New Exodus, particularly pages 50-54.

19 A.R. Ceresko, The Rhetorical Strategy, 53. The animal metaphor has a double designatum, while the two metaphors have different meanings when applied to the servant: the metaphor of a young shoot foretells life, while that of lamb and sheep through its context foretells primarily death.

20 A.R. Ceresko, The Rhetorical Strategy, 52.

21 R. Meynet, Le quatrième chant du Serviteur Is 52,13-53,12, 407-440. 
quent concentric structures are built. The whole song thus seems to have a concentric structure, consisting of three parts: 52:12-53:3; 53:4-7a; 53:7b-12, each of which also has a concentric structure around verses 53:1.5b.10, respectively. Meynet's analysis evinces openness to the text, which itself becomes the carrier of the message. The author verifies the results of his study through referral to various rhetorical criteria, those of form and those of content. Yet, some parts of his analysis may still be reworked and developed.

Meynet's analysis of the text's structure proceeds from inferior levels to superior levels. Instead of beginning with a comprehensive overview of the Fourth Song, he first wants to analyse the smallest units (members and segments). This is risky, as a small textual unit, rhetorically more noticeable than its context, may automatically become for Meynet the centre of a structure, given his predilection for concentric structures. This is most clearly visible in his division of v. 7 into two fragments that are then included in two different parts of the text, despite the fact that the word "sheep" appears in v. 7 in the extreme position. ${ }^{22}$ As a result, Meynet's global view of the poem is derivative, as it needs to correspond to his already established and rhetorically developed smaller units. Bearing this risk in mind, my rhetorical analysis conducted in the subsequent part of this article, while similar in many respects to Meynet's analysis, will begin with a global overview of the poem to proceed to the analysis of its parts only later. Such a global perspective will also make it possible to determine major theological themes of the poem, which do not so much form a binary opposition between degradation and elevation of the servant, but rather focus on the soteriological meaning of his suffering.

\section{Rhetorical analysis of the Fourth Song}

Before embarking on the rhetorical analysis, I would like to discuss some fragments of the Fourth Song, whose rendering in the Masoretic Text poses interpretational problems ${ }^{23}$. My subsequent comments are numbered with the use of letters of alphabet which refer to the appropriate fragment of the text given on the next page. The text is graphically presented in such a structural order in which it will be discussed in the subsequent part of this article.

22 R. Meynet, Le quatrième chant du Serviteur Is 52,13-53,12, 419-420, 422-423.

23 A textual commentary may be found in every commentary on the Book of Isaiah. An indispensable study in this respect is Dominique Barthélemy's Critique textuelle de l'Ancien Testament, 383-407. Due to philological reasons as well as to the comprehensiveness of textual commentary, one can mention here also Jan L. Koole, Isaiah, 263-343. 


\subsection{Textual and philological commentary}

a The proposed translation of the pronoun is the emendation of the $2 \mathrm{sg}$. $\mathrm{m}$. suffix present in MT ("at you"). MT is confirmed by 1 QIs ${ }^{\mathrm{a}}$ and $1 \mathrm{QIs}$, $\mathrm{LXX}$ and Vulg, while the phenomenon of the change of suffix occurs also in many prophetic texts. ${ }^{24}$ The change of the pronoun follows the Syriac and Targumic versions, which perceive $\supset$ 可 (suf. 2 sg. m.) as a mistaken substitution of $i$ (suf. 3 sg. m.).

b The verb יָּ present in MT is translated as "to sprinkle" (in Vulg). The problem with such a translation lies not only in the absence of a synonymous verb in the parallel structure in vv. 14-15, but also in the absence of the preposition עַy, which would signify the indirect object (the object of sprinkling). LXX's translation "will be amazed at" seems to suggest another meaning of the verb נזה, which on the basis of the analogous Arabic verb nazā ("to jump") would mean "to shock, to amaze."

${ }^{c}$ The second part of the verse is rendered parallelly through two consecutive sentences, in the manner similar to Symmachus, which translates ? introducing the verbs "to see" and "to desire" as wāw consecutive.

$\mathrm{d}$ The attributive structure present here indicates the aim of the punishment, hence it should be translated as "the punishment for our peace." 25 The semantic field of the term שָׁi in Deutero-Isaiah is broad: in 45:7 it is the synonym of "light" (אוֹר) and the antonym of "evil" (רע), while in 52:7 it corresponds to "good" (טוֹ) and "salvation" (ישוֹשָּ).

"The translation of the noun דis aseneration" stems from such a meaning of the word in Deutero-Isaiah: 41:4; 51:8[x2].9. ${ }^{26}$

Cf. GKC \$144p.

GKC $\$ 128 \mathrm{q}$.

D.N. Freedman, J. Lundbom, dôr, 179-180. 
${ }^{13}$ Behold, my servant will prosper, he will be raised and lifted up and highly exalted.

${ }^{14}$ As many were shocked at him ${ }^{\mathrm{a}}-$

a

A b

B b

a

A' b

$\mathbf{a}^{\prime}$ so marred was his appearance, beyond that of man, and his form beyond that of the sons of men.

${ }^{15}$ So many nations will be astonished ${ }^{\text {b }}$, kings shall shut their mouths before him,

for what they were not told, they will see, and what they have not heard, they will understand.

${ }^{1}$ Who has believed what we have heard

and to whom has the arm of Yahweh been revealed?

${ }^{2} \mathrm{He}$ grew up before his face like a young shoot, and like a root out of dry ground.

He had no form or majesty that we should see him, and no beauty that we should desire ${ }^{\mathrm{c}}$ him.

${ }^{3} \mathrm{He}$ was despised and rejected by men, a man of sufferings and acquainted with grief;

like one from whom men hide their faces, despised and we held him in no regard.

${ }^{4}$ Surely it was our griefs he bore and our sufferings he carried.

Yet we regarded him as plagued, smitten by God and humiliated.

${ }^{5}$ But he was pierced for our transgressions, he was crushed for our guilts;

the punishment for our peace ${ }^{d}$ was upon him,

and by his wounds we are healed.

${ }^{6}$ All we like sheep went astray, we each turned to our own ways

and Yahweh laid on him the guilt of us all.

${ }^{7} \mathrm{He}$ was oppressed, yet he submitted to be humiliated, he did not open his mouth.

Like a lamb being led to slaughter and like a sheep silent before her shearers, he did not open his mouth.

${ }^{8}$ After oppression and judgement he was taken away, and who considers his generation ${ }^{\text {e? }}$

For he was cut off from the land of the living, for the transgression of my people the striking was upon him.

${ }^{9}$ And they placed his grave with the wicked and with a rich man in his death,

although he had done no violence, and there was no deceit in his mouth.

${ }^{10}$ But Yahweh willed to crush him and put him to pain ${ }^{\mathrm{f}}$.

When he makes his life as compensating gift, he shall see his offspring, prolong his days; and will of Yahweh shall prosper by his hand.

${ }^{11}$ After the travail of his life he will see it and be satisfied.

By his knowledge ${ }^{g}$ my righteous servant will justify MANY, and he will carry their guilts.

${ }^{12}$ Therefore I will give him a portion among the MANY, and he will divide the spoils with the great ${ }^{\mathrm{h}}$, because he poured out his life to death, and was numbered with the transgressors.

For he bore the sin of MANY, and will intercede ${ }^{i}$ for the transgressors.

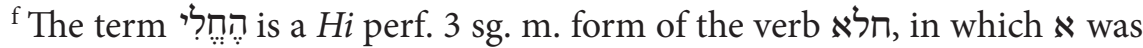
omitted due to the $\boldsymbol{\aleph}$ directly following the term ${ }^{27}$ Thus, there is no need for the emendation into ילחב ("crushed him with pain").

27 A similar phenomenon occurs in 2 Kgs 13:6; Jer 32:35 (cf. GKC \$74k). 
$\mathrm{g}$ The proposed rendering of the first part of v. 11 is based on Koole's textual criticism. ${ }^{28}$ The absence of a direct object that would follow the verb "to see” (ראה) is not rare in Isaiah's text (cf. 41:5; 42:18 etc.), hence the direct object needs to be added on the basis of the context. The context presupposes the development of God's plan according to v. 10; thus, the servant "will see his life." In light of the semantic field of "seeing" in Psa 17:15; Prov 27:20; Eccl 1:8; 4:8, the verb "to be satisfied" present later is a consequence of the realization of God's plan of salvation. For metrical reasons,

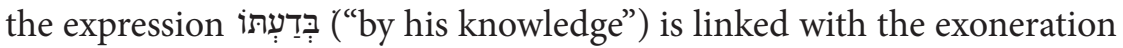
through the servant's offering mentioned later.

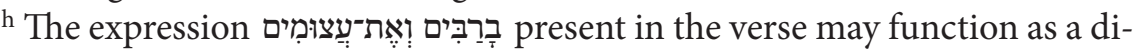
rect object ("I will allot him many and he shall divide the mighty") or as a prepositional phrase, which is suggested in my translation below. Such a translation takes into account אֶ, which appears later in its prepositional meaning ("with the transgressors", v. 12b). The parallel structure imposes a similar meaning on the syntagma in question in v. 12a.

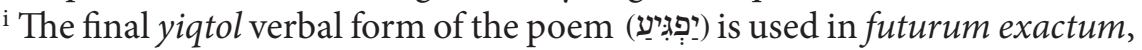
as corroborated by the presence of this form in this sense in v.11 as well as by the inclusion formed by the sentence with 52:13.

\subsection{The structure of the whole song}

The Fourth Song about the servant of Yahweh consists of three parts: 52:1353:3; 53:4-7 and 53:8-12. The central part has the most clear limits marked by two terms used as extreme terms: "humiliate/afflict" (ענה) and the personal pronoun "he" (הוּא) in v. 4a and v. 7a. Thematically speaking, the part focuses on the servant's suffering and affliction, signalled in v. 3a and developed since

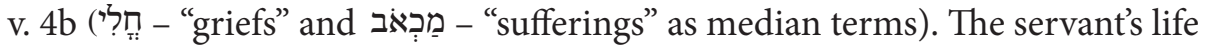
changes in v. 8 , which foretells his death.

The delimitation of the first part is formally confirmed by the motif of elevation in 52:13 ("he will be raised and lifted up and highly exalted") and in 53:2 ("he grew up" as an extreme term).

The final part makes use of a few extreme terms. Its beginning and ending are marked by the presence of the word "death" (מָוז) in vv. 9a.12b. The expressions "lead to slaughter" (v. 7c), "cut off from the land of the living" (v. 8b) and "grave" (v. 9a) also belong to the semantic field of death. What is more, the

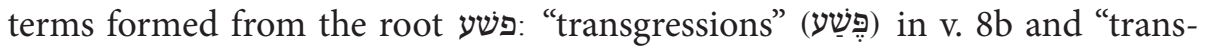

28 J.L. Koole, Isaiah, 328-330. 


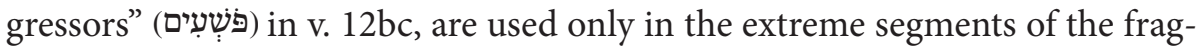
ment analysed in the present article.

\subsection{Isa 52:13-53:3: elevation through suffering}

\subsubsection{The structure of the first part}

The first part consists of three pieces: a (vv. 13-15); b (v. 1); a' (vv. 2-3), which have a concentric structure.

The delimitation of these pieces is clear thanks to the use of several extreme terms. The first piece a is delimited by two terms that are used as opposites: "servant" (v. 13) and kings (v. 15a). The opposition stems both from the grammatical form (the servant is one, the kings appear in the plural) and from semantic reasons (opposition between serving and ruling). The third piece (a') is delimited by the term "face" (vv. 2a.3b). Piece b (v. 1) situated in the centre consists of two parallel members in which the interrogative pronoun appears. Furthermore, the extreme pieces begin with the terms that belong to the semantic field of elevation, applicable here to the servant: v. 13 predicts that "he will be raised and lifted up and highly exalted," while v. 2a maintains that "he grew up like a young shoot".

The concentric structure is corroborated by numerous repetitions in the extreme pieces. These are first the expressions used to describe the physical

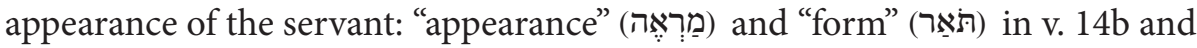
v. 2b. The word "face" used in piece a' (vv. 2a.3b) belongs to the same semantic field. Later, there are verbs expressing people's reactions to the servant's appearance. The verbs used in the first piece: "be shocked (שמם) in v. 14a and "be astonished" (נזה) in v. 15a correspond to the verbs "desire" (חמד) in v. 2b, "despise" (בזה) in v. 3ab and "esteem, consider, hold in regard" (חשב ) in v. 3b. Both extreme pieces make use of the verb "to see" (ראה) in v. 15b and v. 2b. Finally, it is only in the extreme pieces that words preceded by the negation "not" appear: v. $15 \mathrm{~b}$ and vv. $2 \mathrm{~b} .3 \mathrm{~b}$.

\subsubsection{Internal dynamism of the first part}

\section{a) Relation between pieces a and a'}

The connections between the extreme pieces of the first part include, first of all, the motif of elevation. Both pieces link this elevation with God: piece a (v. 13) does so by calling the servant the servant of God ("my servant"), while piece 
a' - by situating the servant before God's face ("before his face" in v. 2a). The people's reaction to the servant is different, though. Even though both pieces refer to the future, predicting the triumph of the suffering servant, this is explicit only in the first piece ("behold, my servant will prosper"). The prediction in the final piece is ambivalent, as the extraordinariness of the servant's life seems to refer to the moment of his rejection by the people.

The reason for the servant's rejection is rendered in a similar way in both pieces: it is the servant's physical appearance that generates disgust (v. $14 \mathrm{~b}$ and v. 2b). Piece a' goes further, identifying the servant's suffering as the cause of his deformity ("a man of sorrows and acquainted with grief," v. 3a). The reaction of the people rejecting the servant is depicted in two stages. The first piece draws attention to the external aspect of this rejection ("be shocked," v. 14a; "shut their mouths," v. 15a), while the last piece emphasizes the internal aspect of rejection ("despise," v. 3ab; "not esteem, hold in no regard," v. 3b).

The complementary character of the two pieces is also evinced in the identification of the subject rejecting the servant. The first piece mentions in this context a group described as "many" (v. 14a), "many nations" (v. 15a) and "kings" (v. 15a), while the third piece identifies "men" (v. 3a) as the subject admitting to the rejection of the servant ("we", vv. 2b.3.b).

\section{b) Relation between pieces a and b}

The pieces are linked by the motif of cognition, expressed with the verbs "understand" (בין) in v. 15b and "believe" (אמן) in v. 1a. People's recognition of the servant is a consequence of God's revelation, as made clear by the question in v. 1a ("to whom has the arm of Yahweh been revealed (גלה)?"). Both units also stress the unique character of this revelation: the first speaks of "what they were not told" and "what they have not heard" (v. 15b), while the second one achieves this through a question trying to identify those who will accept the revelation (v. 1).

\section{c) Relation between pieces $b$ and a'}

The link between these two pieces is formed by the servant's connection to God. Since he is considered by God a "young shoot" and a "root out of dry land" (v. 1), God needs to reveal this to those who reject his servant (v. 1ab). In light of this, the confession of the speaker in piece a' seems to result from accepting God's perspective on the suffering of the servant. 


\subsection{Isa 53:4-7: the revision of the assessment of the servant's suffering}

\subsubsection{The structure of the second part}

The second part is characterized by the presence of numerous synonymous expressions: in v. 4a "griefs"||"sufferings" and "bear"||"carry"; in v. 5a "our transgressions"||"our guilts" and "pierced"||"crushed"; in v. 5bc "peace"||"healing"; in v. 6a "all we"||"we each" and "go astray"||"turn to one's own way"; in v. 7a "submit to be humiliated"||"not open the mouth" in v. 7ab. The fragment can be divided into three pieces, forming a concentric structure: a (vv. 4-5a); b (v. 5bc); a' (vv. 6-7).

The delimitation of the third piece is not problematic, as its limits are marked by extreme terms referring to the "sheep" (צאן in v. 6a; רֶח in v. 7b). The limits of the first piece are marked by the 1 pl. suffixes in vv. $4 \mathrm{a} .5 \mathrm{a}$, which link the servant's plight to the guilt of those who witness his suffering. The second piece stands out by virtue of the synonymous parallelism present there: the servant's suffering turns out to be "peace" (שָׁi in v. 5b) and "healing" (the verb רפא in Ni in v. 5c) for those who observe what he goes through.

Speaking of the part's concentric structure, it needs to be added that it is also noticeable in the form of the extreme pieces. Both have in their centre the members mentioning God's name and his actions as regards the servant (v. 4b.6b).

\subsubsection{Internal dynamism of part two}

\section{a) Relation between pieces a and a'}

The pieces stand in opposition to each other. This is shown most clearly by a comparison of their central members, which evaluate God's actions towards the servant. V. $4 \mathrm{~b}$ constitutes a mistaken interpretation of God's actions (the subject of this assessment is indicated by the expression "yet we"), while v. $6 \mathrm{~b}$ corrects it.

The change in the assessment of the servant's suffering goes hand in hand with the correction of the speaker's self-evaluation. The first piece underlies the subject's communal (anonymous) character (personal pronoun "we" in v. 4b; 1 pl. possessive pronoun in vv. $4 \mathrm{a} .5 \mathrm{a}$ ), while the last piece accentuates its personal aspect, stemming from the quantifier "each" (three times in v. 6). The pieces differ in their presentation of the speaker's participation in the suffering of the servant: piece a links the speaker's "guilts" and "transgressions" (v. 5a) 
with the "griefs" and "sufferings" of the servant (v. 4a), while piece a' clarifies their "guilt" as going astray and turning to their own ways.

The opposition between the two pieces is finally confirmed by the relation between the speaker and the suffering servant. First, there is a difference in terms of speech: the 1 pl. speaker actually speaks ("regard" in v. 4b), while the servant remains silent ("not open his mouth" in v. 7ab). Further, the speaker concentrates on themselves ("turn to one's own way" in v. 6a), which is contrasted to the servant's actions for the sake of others (he suffers "for our transgressions" and "for our guilts" in v. 5a).

b) Relation between the central piece and extreme pieces

The concentric structure of the second part is based primarily on the interpretation of the servant's suffering, which occurs three times in vv. $4 \mathrm{~b} .5 \mathrm{bc} .6 \mathrm{~b}$. The assessment in the central part - "peace" (v. 5b) and "healing" (v. 5c) - adds a soteriological dimension to the servant's experiences.

\subsection{Isa 53:8-12: The expiatory value of the servant's suffering and death}

\subsubsection{The structure of the third part}

Three pieces forming a concentric structure can be identified within the third part: a (vv. 8-9); b (v. 10); a' (vv. 11-12).

The limits of the second piece are marked by the combination of Yahweh's name with the root חפץ, denoting "desire, wanting, will" (extreme term): in v. 10a Yahweh is the subject of the verb "to will", while in v. 10c Yahweh is the attribute of the noun "will". The central piece thus focuses on God's will as regards the servant.

In the third piece the words that function as extreme terms are: "his life" (

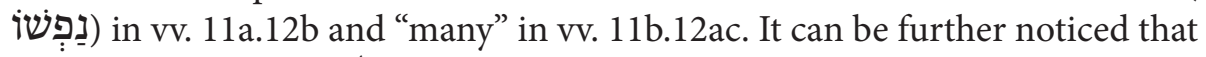
the expression "carry (סבל) guilts" in v. 11b corresponds to the phrase "bear (נשא) sins" in v. 12c. Finally, there is an opposition between the servant, who is called "righteous" in v. 11b, and the "many", characterized as "transgressors" (v. 12bc).

As a result, vv. 8-9 should be considered a separate unit. As far as its theme is concerned, the unit depicts chronologically the events that led to the servant's death: the court case ("oppression and judgement", v. 8a), death ("cut off from the land of the living", v. 8b) and funeral ("placed his grave", v. 9a). 


\subsubsection{Internal dynamism of part three}

a) Relation between extreme pieces

The concentricity of this part evinces the opposition between extreme pieces, which focus on the servant. In the opening piece, the servant is passive and he falls victim to violence. A gentle man himself (v. 9b), he experiences violence and deceit (v. 8). By contrast, in the closing piece the servant is active: he "justifies" (v. 11b) and "intercedes" (v. 12c); what is more, he agrees to his own death ("pour out his life to death" in v. 12b).

The servant's fate is likewise presented differently in the two pieces. According to the first one, his destiny is death, whose finality is marked by the "grave" (v. 9a). The last piece, however, offers a different perspective on the servant's suffering: after his "travail" (v. 11a), "he will see it [life] and be satisfied" (v. 11a), "he will divide the spoils" (v. 12a) and "he will intercede for the transgressors" (v. 12c).

Finally, the contrast between the presented consequences of the servant's death for others may be mentioned. While piece a underlies the totality of the servant's death, which precludes having any offspring (v. $8 \mathrm{a})^{29}$, piece a' points to the redeeming consequences of his death, which will affect "many" (vv. 11b.12ac). Not having any progeniture himself, the "many" will become his offspring (v. 12a).

b) Relation between the central piece and extreme pieces

The central piece links the servant's experiences with God. His suffering is the realization of God's will (v. 10ac). This will is not limited to crushing the servant and putting him to pain (v. 10a), described in piece a, but encompasses the lifegiving results of his death (v. 10c), developed in piece a. The centre of part three is occupied by v. $10 \mathrm{~b}$, which indicates the route from the servant's death to life:

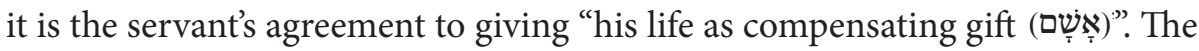
expression אָשָ connotes a reparatory offering for sins, thereby being linked to v. $8 \mathrm{~b}$ ("for the transgression of my people the striking was upon him"), v. 11b ("he will carry their guilts") and v. 12c ("he bore the sin of many"). The servant's death thus has an expiatory character. 


\section{The theology of the Fourth Servant Song}

The analysis of the song's structure conducted above shows that the concentric structure of all the three parts expresses more than just the opposition between the extreme pieces, which differ in their description of the servant's situation and its assessment by witnesses. As a matter of fact, each of the parts conveys a change in the perception and understanding of the servant's experiences. The moment of transformation is rendered in the central pieces (53:1.5bc.10). For this reason, the theology of the poem is not static but dynamic as it turns into a debate over the sense of suffering.

\subsection{The rhetorical structure of Isa 52:13-53:12 as testimony to the debate over the value of suffering}

The participants in the debate include God, people (the prophet) and the servant himself. Only the voices of the first two can be heard, but the speaker communicates non-verbally, disclosing his own understanding of the experiences he undergoes. The analysis of the relations between individual parts will enable one to capture major theological arguments of the discussion.

\subsubsection{The servant's and Israel's differing perspective on suffering (relation between extreme parts A: 52:13-53:3 and A': 53:8-12)}

The extreme parts expose primarily the mutual relation of the servant and the speaker in $1 \mathrm{pl}$. Using the same words and expressions with reference to both of them, the text characterizes them emphasizing the contrast between their reactions to suffering.

Both subjects will "shut their mouths". Part A (v. 15a) emphasizes the fact that those who witness the servant's suffering ("many nations", "kings") shut their mouths as an expression of their astonishment at both the servant's physical appearance (v. 14) and their own difficulty understanding the meaning of his suffering (v. 15b). By contrast, the servant's silence in part A' corroborates his innocence (v. 9b).

These varied reactions to suffering derive from different perspectives on the events depicted in the song. The witnesses to the servant's plight multiply their words in the attempt to explain the servant's situation. They become silent only when they understand the sense of the unfolding drama ("see" and "understand" in 52:15b). Silence as understanding is the servant's trait from the very beginning. The awareness that his suffering is part of God's plan (53:10) 
becomes for him the "knowledge" (53:11b) that enables his to submit fully to God's will. The drama depicted in the song is thus the drama of cognition and recognition of the sense of the ongoing plight (cf. the verb "to reveal" in 53:1b).

To understand suffering, one needs to see. It is seeing that juxtaposes in the extreme pieces the mutual reactions of the servant and those who witness his life. While in A people turn their faces away from the suffering servant, deeming him unworthy of attention (vv. 2b-3), the rejected servant will see his offspring after his travails are over (v. 10b). This paradox strengthens the link between the servant's life and the "land". Part A speaks of the ultimate victory of the servant, comparing him to the "root out of dry ground" (v. 2a), while part A' presents his death as being "cut off from the land of the living" (v. 8b). Hence, the one who is considered dead gives life to those who take themselves for the living.

The opposition between the attitudes of the servant and the people emphasized above stems from their differing abilities to read God's will in history. Both the servant and the people are treated by God as his special property (cf. the possessive pronoun "my" used with reference to the servant in 52:13a; $53: 11 \mathrm{~b}$ and to the people in 53:8b). The people's belonging to God is not reflected, however, in their understanding of God's will, realized through the suffering servant (cf. 53:1a.10c). In this context, the identity of those who witness the servant's suffering may be identified. This is a community linked to God that the servant belongs to. The expression "my people" (53:8b) constitutes a fragment of the covenant formula. For this reason, it seems justified to identify the witnesses of the servant's suffering with the people of Israel. Even though the speaker in the song changes (Yahweh in 52:13-15 and in 53:7-12; Israel in 53:1-6), there can be no doubt that the community speaking in $1 \mathrm{pl}$. is the same community that is spoken about in the remaining fragments.

\subsubsection{The evolution of Israel's perspective on the suffering} of the servant (relation between parts A: 52:13-53:3 and B: 53:4-7)

The relation between the first two parts is strictly connected with the people's assessment of the suffering of the servant. The transition from part A to part B signals a correction of the witnesses' stance.

The verb "to regard" (חשב) functions as a median term between the two parts. In v. 3b it expresses Israel's lack of appreciation for the servant - who the people deem valueless - to then in v. $4 \mathrm{~b}$ serve to add that this opinion can be applied to the servant's relation with God, who is allegedly punishing him.

The difficulty with interpreting the fragment lies, therefore, in the people's perspective on the servant's suffering. While in v. 3 the people perceive suf- 
fering as merely a characteristic feature of the servant, in v. 4a they discover that his suffering is in fact a result of his taking over of their griefs. The evolving understanding leads them to realize that the servant's "wounds" are their "peace" and "healing" (v. 5bc). This change in the witnesses' understanding of the servant's suffering results from their realization of their own situation of death. The moment they realize that the servant's suffering is brought about by their "transgressions" (v. 5a) and "guilts" (v. 5a.6b), they are able to correctly understand the servant's experiences in the context of their own lives (v. 5bc).

\subsubsection{God's perspective on the servant's suffering (relation between part $B$ :} 53:4-7 and part $\left.A^{\prime}: 53: 8-12\right)$

The basic difference between these two parts stems from their having two different speakers: in part B it is Israel, while in part A' it is God himself. For this reason, part A' offers a more profound view on the servant's suffering, this time from the perspective of God, who reveals the meaning of the servant's plight for Israel.

Both parts ultimately confirm the servant's innocence, first through the image of sheep. When applied to Israel, the image emphasizes the nation's going astray (v. 6a), while in the case of the servant (v. 7b), it stresses his humility, gentleness and obedience to God's will (v. 10). Another moment confirming the servant's innocence is when God straightforwardly states the mistake the nation has made in their assessment of the servant. They considered him one of the "transgressors" (v. 12b; cf. v. 9a) and the "rich" (v. 9a), "although he had done no violence, and there was no deceit in his mouth" (v. 9b).

The soteriological meaning of the servant's experiences is likewise developed. The "peace" and "healing" mentioned in the central part (v. 5bc) turn out to be an exoneration for those whose guilts have been placed upon the servant (v. 11b). The redemptive dimension of the servant's experiences is made possible by God's actions. The servant's suffering is part of God's plan. Part B claims that "Yahweh laid on him the guilt of us all" (v. 6b), whereby, as part A' emphasizes, it is Yahweh's will that is realized through all this (v. 10c).

\subsection{New vision of suffering in the Fourth Servant Song}

To emphasize the dynamic character of the theological debate over suffering evolving in the poem, its concentric structure can be rendered schematically through titles given to individual pieces. 

v. $13-$ v. 3
the servant's elevation
A
v. 1
the arm of Yahweh
vv. 2-3
the servant's rejection
$\begin{array}{ll}\text { B } & \text { v. } 4-5 \mathrm{a} \\ & \text { v. } 5 \mathrm{bc} \\ & \text { vv. } 6-7\end{array}$
the servant's rejection
Israel's salvation
the servant's rejection
vv. $8-9$
A' v. 10
the servant's death
vv. 11-12
the will of Yahweh
the servant's elevation

The relations between the parts seem to go beyond the concentric structure. The repetition of some elements in the units analysed enables one to consider the Fourth Servant Song a testimony to the theological revision of human suffering. This revision occurs through three motifs developed in the poem: the will of God, the sense of the servant's suffering, and the route to elevation and life.

The question posed by the people in part A: "to whom has the arm of Yahweh been revealed" (v. 1b), raises the issue of God's will, which seems incomprehensible in the face of the servant's suffering. Witnesses to the servant's experiences need God's enlightenment to grasp the sense of this event for their own lives. Part B shows a turning point in Israel's understanding of Yahweh's will. The shift from a mistaken interpretation (v. $4 b$ ) to the right one (v. $6 \mathrm{~b}$ ) is possible thanks to the people's admission of their participation in the plight of the servant. It turns out that he suffers on account of Israel's guilts (vv. 5a.6). Part A' brings the final explanation of the logic behind God's actions, as it states directly that God's will is realized through the servant's suffering (v. 10).

An acknowledgement of the events from the servant's life as expression of God's will is not tantamount to an automatic understanding of the sense of his suffering. Part A is unforthcoming when it comes to indicating the reasons for the servant's suffering. Anticipating his final triumph, it stresses only his rejection by the people caused by the external aspect of his suffering (vv. 2-3). It can be deduced, however, that their distance from the servant encompasses their negative assessment of the servant himself: if he suffers, he must be suffering for his own sins.

It is in part B that there occurs a shift from a negative assessment of the suffering servant (v. 4b), which would corroborate an intuitive understanding of the reasons for his plight mentioned above, to a positive assessment, which turns into Israel's confession of their guilts (vv. 4a.5a.6). In its centre, and there- 
by in the centre of the whole poem, there is $\mathrm{v} .5 \mathrm{bc}$, which reveals the soteriological sense of the servant's suffering for the sinful people.

The final part adds God's own explanation of the servant's suffering: God's will is realized through it (v. 10ac). This will encompasses both the life of the servant, who "shall see his offspring [and] prolong his days" (v. 10b), and the life of the people, whose guilts the servant is suffering for. The verb "to justify" (v. 11b) becomes the synonym for this new life. Ultimately, Israel will partake of the servant's "justice". The servant's suffering thus has a reparatory value rather than expiatory one: through the offering of the servant's life, the people are brought into a life-giving community with God (v. 10b).

The Fourth Servant Song shows people the way to life, which is what God desires for them. The future elevation and life is not only a gift for human beings, but also a task for them to complete. At the beginning of the song the servant's future elevation is predicted (v. 13a), but this motif is not further developed in part $\mathrm{A}$. The dominant motif in this part is the people's rejection of the servant. Rejecting the servant and the offering of his life (cf. verbs belonging to the semantic field of seeing in vv. 2-3), Israel deprives themselves of the life that the servant brings (v. 2a).

Another moment bringing death is the rejection of the truth about themselves. Part B emphasizes that as long as the people do not admit to their sins, they will not have access to the "peace" and "healing" that the servant brings (v. 5bc).

The final part ultimately confirms that it is only by acknowledging the truth of one's own sins and by accepting the servant's exonerating offering that one can receive life. This dialectics of acceptance and rejection is ultimately applied to the acceptance or rejection of God's will. The history of Yahweh's servant shows positive consequences of accepting God's will. V. 10 emphasizes the fact that one's acceptance of God's will and trust towards it - even at those moments that seem to negate God's presence - is a guarantee of life.

The rhetorical analysis of Isa 52:13-53:12 conducted above shows the validity of examining the text's structure to capture its theological meaning. The theology of a biblical pericope does not surface as a final outcome of the exegetical analysis; rather, it gets crystallized at every stage of textual interpretation, especially during the examination of the text's structure. An analysis of the text's structure should thus not aim to order the text by distinguishing its smaller or bigger units. An understanding of a text's internal organization should disclose relations between the units and this way indicate those elements that function 
as major semantic motifs, which would translate into theological motifs. This gives one precise information for exegetical analysis that makes it possible to focus on these words and expressions that constitute the theological wealth of a given text.

The proposed structure of the Fourth Servant Song makes it possible to claim that the theology of the poem is not limited to the opposition between the servant's elevation and humiliation or to divergent assessments of his suffering. These two opposites are not static or constant. The dynamic character of the song lies in the revelation of the possibility and necessity of passing from death to life. For the servant, this happens through his suffering, which in God's redemptive plans turns into an offering that leads sinners into a lifegiving community with God.

\section{Bibliography}

Baltzer K., Deutero-Jesaja (KAT 10/2), Gütersloh: Gütersloher Verlagshaus, 1999.

Barré M.L., Textual and Rhetorical-Critical Observations on the Last Servant Song (Isaiah 52,13-53,12), CBQ 62 (2000) 1-27.

Barthélemy D., Critique textuelle de l'Ancien Testament. 2. Isaïe, Jérémie, Lamentations (OBO 50/2), Göttingen: Vandenhoeck \& Ruprecht, 1986.

Berges U., Jesaja 49-54 (HThKAT), Freiburg-Basel-Wien 2015.

Blenkinsopp J., Isaiah 40-55. A New Translation with Introduction and Commentary (AB 19), New York: Doubleday, 2000.

Bonnard P.-E., Le Second Isaïe, son disciple et leur éditeurs. Isaïe 40-60 (Études bibliques), Paris: J. Gabalda, 1972.

Brzegowy T., Prorocy Izraela, I, Tarnów: Biblos, ${ }^{2} 1994$.

Cazelles H., Les Poèmes du Serviteur. Leur place, leur structure, leur théologie, RSR 43 (1955) 5-51.

Ceresko A.R., The Rhetorical Strategy of the Fourth Servant Song (Isaiah 52,13-53,12).

Poetry and the Exodus-New Exodus, CBQ 56 (1994) 42-55.

Childs B.S., Isaiah (OTL), London-Leiden: Westminster John Knox, 2001.

Conroy C., The 'Four Servant Poems' in Second Isaiah in the Light of Recent Redaction-Historical Studies in Biblical and Near Eastern Essays. Studies in Honour of Kevin J. Cathcart, ed. C. McCarthy and J.F. Healey (JSOTSup 375), London: T \& T Clark, 2004, 80-94.

Coppens J., Le Messianisme et sa relève prophétique. Le anticipations propétiques, leur accomplissement en Jésus, Gembloux: Duculot, 1974.

Duhm B., Das Buch Jesaja (HAT 3/1) Göttingen: Vandenhoeck \& Ruprecht, 1892.

Freedman D.N., Lundbom J., dôr, in TDOT, III, 169-181.

Grelot P., I canti del servo del Signore. Dalla lettura critica all'ermeneutica (Studi Biblici 9), Bologna: EDB, 1983. 
Marconcini B., Księga Izajasza (Rozumieć Stary Testament), Kraków: Wydawnictwo M, 2000.

Meynet R., Le quatrième chant du Serviteur Is 52,13-53,12, Gregorianum 80 (1999) 407-440.

Meynet R., Wprowadzenie do hebrajskiej retoryki biblijnej (Myśl Teologiczna 30), Kraków: WAM, 2001.

Orlinski H.M., The so-called 'Servant of the Lord' and 'Suffering Servant' in Second Isaiah in Studies on the Second Part of the Book of Isaiah (VTSup 14), Leiden: Brill, 1977, 3-133.

Oswalt J.N., The Book of Isaiah. Chapters 40-66 (NICOT), Grand Rapids: Eerdmans, 1998.

Orlinski H.M., The so-called 'Servant of the Lord' and 'Suffering Servant' in Second Isaiah in Studies on the Second Part of the Book of Isaiah (VTSup 14), Leiden: Brill, 1977, 3-133.

Paściak J., Izajasz wieszczem Chrystusa (Attende Lectioni 12), Katowice: Wydawnictwo św. Jacka, 1987.

Raabe P.R., The Effect of Repetition in the Suffering Servant Song, JBL 103 (1984) 77-84.

Schenker A., Knecht und Lamm Gottes (Jesaja 53). Übernahme von Schuld an Horizont der Gottesknechtslieder (SBS 190), Stuttgart: Verlag Katholisches Bibelwerk, 2001.

Snaith N.H., Isaiah 40-66. A Study of the Teaching of the Second Isaiah and Its Consequences in Studies on the Second Part of the Book of Isaiah (VTSup 14), Leiden: Brill, 1977, 139-146.

Stachowiak L., Księga Izajasza II-III (40-60). Wstęp - przekład z oryginału - komentarz-ekskursy (PŚST 11/2), Poznań: Pallottinum, 1996.

Westermann C., Isaiah 40-66. A Commentary (OTL), London: SCM, 1969.

Whybray R.N., Isaiah 40-66 (NCBC), Grand Rapids: Eerdmans, 1975, 169-170. 